\title{
Gelecek Olan Halk ya da Toplum 5.0: Hakikati Araştırma ve Masal Yaratma İlişkisi Bağlamında Toplumu Koruma Fikri
}

\author{
People to Come or Society 5.0: The Idea of Protecting Society in the Context of \\ the Relationship between Searching for Truth and Fabulation
}

\author{
SİNAN KÜRKÇÜ* \\ * Dr. Lect., Bahçeşehir University, Faculty of Medicine, Sahrayı Cedid Mahallesi, Batman Sokak, No: 66-68, \\ Yenisahra-Kadıköy, İstanbul, Turkey, E-mail: sinankurkcu@hotmail.com \\ (D) https://orcid.org/0000-0003-3635-6327
}

Öz: Makalede, Toplum 5.0 olarak adlandırılan sürece bağhl olarak sosyal korumanın, esasen geniş bir perspektifle toplumu koruma fikrinin nasıl biçimlenebileceği incelenmektedir. Buna uygun olarak, gelecek olan halk kavramsallaştırmasıyla, düşüncenin ve bilginin değişen koşullarına işaret edilmektedir. Gelecek olan halk ile toplumu koruma fikri arasındaki ilișkinin, değișmekte olan düșünce ve bilgi koșulları açısından bir görünümü sunulmuștur. Gelecek olan halkın Toplum 5.0 gelişmeleriyle sosyal koruma bağlamında nasıl biçimlenebileceği, ne türden bir toplumsal perspektif üretebileceği sorunsallaștırılmaktadır. Düşünce üretiminin bilgi koşullarıyla ilişkisi, diğer deyişle güncel olarak bilimsel araștırmayı ve teknolojik gelişmeyi öncelikli bir toplumsal ufuk olarak belirleme meselesi, sosyal korumanın yeni bilimsel ve toplumsal koșullarla kavranabilmesi yönünde değerlendirilmiștir. Bu halde, hakikati araștırma ve toplumsal masal yaratma kavramlarının birbirine yakınsamasıyla ifade edilen bir bakış açısını, toplumu koruma fikri bağlamında anlayabilmek amaçlanmaktadır. Sonuç olarak dijital temelli toplumsallığa yönelisin sosyal korumayla ilişkisine, dönüştürücü bir toplumsal tasarımın içinde taşıyabileceği koruma fikri ve pratiklerinin ortak iyiler yönünde geliştirilmesi açısından işaret edilmiştir.

Anahtar kelimeler: Gelecek olan halk, Toplum 5.0, Hakikati araştırmak, Masal yaratmak, Sosyal koruma

Abstract: In this article, it is examined how social protection, essentially the idea of protecting society with a wider perspective, can be shaped depending on the process called Society 5.0. Accordingly, the changing conditions of thought and knowledge are pointed out with the conceptualization of people to come. A view of the relationship between people to come and the idea of protecting society is presented in terms of the changing conditions of thought and knowledge. It is problematized how people to come can be shaped in the context of social protection with the developments of Society 5.0 and what kind of social perspective it can produce. The relationship of thought production with the conditions of knowledge, in other words, the issue of determining scientific research and technological development as a priority social horizon today has been evaluated in terms of understanding social protection with new scientific and social conditions. In this case, it is aimed to understand a point of view expressed by the convergence of the concepts of searching for truth and fabulation, in the context of the idea of protecting the society. As a result, the relationship of digital-based sociality with social protection is pointed out in terms of the development of the idea and 
practices of protection that a transformative social design can carry in the direction of common goods.

Keywords: People to come, Society 5.0, Searching for truth, Fabulation, Social protection

\section{Giriş}

Kendisi de bir akış dinamiği halinde üremekte olan yaşamın peşi sıra, hakikatin (gerçeğin) aranması vasıtasıyla bizzat üretiminde, hakikati araştırmanın bilimsel biçimleri ve muhtelif toplumsal biçimleri; gözlem ile deneyim, akıl ile güdü gibi farklı yönlerle sürekli olarak karşılaşır ve zihin dünyamızda kurulurlar. Araştırma biçimlerinin birinden diğerine geçerek, bunları durmaksızın birbirine geçirerek, karşılaşmalar yaşanmakta, deneyimlenmektedir. Bu bakımdan deneyimle (ya da deneyle) bilgi güncelleşirken, bu yolla düşünceyi de canlandırması ve yenilemesi, düşüncenin bir sınırlı alan içinde değil, dışarının etkisiyle ortaya çıkışı bakımından bir semptom gösterir. Bu bakış açısıyla, yapısalcılık sonrası düşünce tarihinin ana uğraklarından biri olan dışarı düşüncesi (la pensée du dehors $)^{1}$ temelinde, gelişmekte olan bir fenomeni irdelemek, ilişkiselliğe ve etkileşimlere duyarlı bir kavrama zemini sunabilecektir. Burada dışarı (dehors), herhangi bir çokluğun (multiplicité) dışını değil, bu çokluğu oluşturan muhtelif kuvvet ilişkilerinin bir diğer kuvvet ilişkileri bloğuyla temas halinde oluşunu, birlikte değişmekte oluşlarını belirtir. Sürekli olarak dışarıda kurulmakta ve dağılmakta olan çoklukların kavranışı ve değerlendirilişi üzerinden değişimi anlayabilmenin bir yaklaşımdır. Bu sayede, yaşamın enformasyon işleyerek çeşitli türlerden unsurlar oluşturmasında, doğanın kendi üretimi ile söz konusu dönemin bilimsel ve toplumsal üretimlerinin bir arada sağlamakta oldukları düşünce ve bilgi ağlarının işleyiş tarzları, etkileşimleri ve imkânları geniş bir açıdan gözetilebilir. O nedenle Toplum 5.0 gibi kapsamlı bir gelecek perspektifinin içerebileceği düşünce ve bilgi ağlarını bir ölçüde anlayabilmek ve bunu belirli bir meseleyle (toplumu koruma fikri) birlikte sorunsallaştırabilmek, esasen hem bu gelecek perspektifinin kendisine hem de bunu incelemek üzere seçilen ve çalışmaya hitap eden bazı kavramlarıyla açımlanacak olan düşünsel zemine uygun olacaktır.

Yakın geçmişimizi ve bir dereceye kadar günümüzü tanımlamakta kullanılan bilgi toplumundan bir sonraki evre olarak dolaşıma girmekte olan bir düzlem olan Toplum 5.0 kavramı, Japonya tarafından dünya gündemine getirilmiştir. Toplum 5.0’ın ileri sürülmesine imkan veren, kavramın farklı boyutlarıyla değerlendirildiği çalışmalarla, insanlık tarihi temel olarak beş farklı döneme ayrılmıştır. Buna göre Toplum 1.0 (Avc1-Toplayıcı Toplum) doğa içinde avc1-toplayıcı insan topluluklarını, Toplum 2.0 (Tarım Toplumu) tarıma başlayan, kurumlaşmanın ilk örneklerini oluşturan toplumları, Toplum 3.0 (Sanayi Toplumu) sanayileşmeyi ve ilgili üretim biçimlerini sergileyenleri, Toplum 4.0 (Bilgi Toplumu) bilgi ağları sayesinde değişim ve gelişim sağlayabilen toplumları ifade etmektedir. İnsanlık tarihinde beşinci evreyi oluşturacak olan Toplum 5.0 ise kısaca, değişen teknolojinin insanlığa fayda için yönlendirileceği, insan merkezli akıllı toplumun bu yolla tesis edileceği, koşullara işaret etmektedir. ${ }^{2}$ Tarihsel süreçte gerçekleşen tarımsal ve en-

${ }^{1}$ Michel Foucault, "Dışarı Düşüncesi”, Sonsuza Giden Dil, Seçme Yazılar 6, der., Işsk Ergüden ve Tuncay Birkan, çev., Işık Ergüden, İstanbul: Ayrıntı Yayınları, 2014, s.192.

2 "Realizing Society 5.0", The Government of Japan, erişim 12 Mart, 2021, https://www.japan.go.jp/abenomics/ 
düstriyel devrimler, bilimsel ve teknolojik ilerlemelerle bir arada sosyal yapıda değişimler ve dönüşümler üretmiştir. Bu bakımdan geçmişin tüm deneyimlerinin 1ş1ğında artık Toplum 5.0'ın insanı ve toplumu temel alan, sosyal sorunların çözümüne bilimsel ve teknolojik gelişmelerle odaklanan, bu sayede akıllı bir toplumsallığa ulaşabilmenin amaçlandığı devrimsel bir dönüşüm sağlaması düşünülmektedir.

Esasen 21. yüzyılla birlikte yaygınlaşan yapay zekâ, robotik, büyük veri, nesnelerin interneti gibi teknolojilerin gelişimi endüstriyel (ve finansal) yapıların dönüşüm sürecinde etkin bir rol sergilemektedir. Söz konusu dönüşüm Almanya menşeli Endüstri 4.0 kavramı ile ifade edilebilirken, diğer taraftan bunun bir akıllı toplum zemininde yürütülüp genişletilmesi fikri ise Japonya'da Toplum 5.0 kavramının doğuşunu sağlamıştır. Toplum 5.0, öngörülebilir gelişmelerin sosyal yaşama yönelik etkilerini de dikkate alan kapsamlı bir bakışla, gelecek olan bir toplumsallı̆̆ın düşünülme gereğine işaret eder. Diğer bir deyişle, insan yaşamını merkezine almak suretiyle Endüstri 4.0'dan farklı bir kavramsallaştırmadır. ${ }^{3}$ Bir gelecek perspektifi olarak Toplum 5.0, Endüstri 4.0'ın getirmekte olduğu yeniliklerin ancak toplumsal değişimi ön plana almak suretiyle entegre edilerek sorunlara çözümler üretilebileceği, teknolojinin toplumsal faydaya kanalize edilerek insan odaklı bir akıllı toplumsallık fikri sunulabileceği iddiasındadır.

Diğer yandan bu türden yeni bir toplumsallığın, yaşam içinde yer bulmakta olan muhtelif pratikleri ne yönde etkileyebileceği güçlü tartışma konuları ortaya çıkarmaktadır. Bunlardan biri de çalışmada ele alınan sosyal koruma olgusunun ve daha ötesinde toplumu koruma fikrinin, değişim ve hatta dönüşümün mevcut olduğu koşullarda nasıl biçimlenebileceği üzerinedir. Bu husus özellikle köklü bir dönüşüm ile koruma fikri ve pratiklerinin birlikte nasıl var olabileceğine dair bir düşünme sahası oluşturmasıyla dikkate değerdir.

O nedenle özgül olarak dışarı düşüncesi üzerine temellenen fikirsel bir zeminde, Toplum 5.0 bağlaminda gelecek olan halk ya da henüz olmayan halk ${ }^{4}$ olarak isimlendirilen bir kavramsallaştırma değerlendirilecektir. Bu vasıtasıyla düşüncenin ve bilginin değişen koşullarına işaret etmek, böylece gelecek olan halkın sosyal koruma açısından ortaya çıkabilecek olan değişimini, düşünce ve bilgi koşulları bakımından kavramak mümkün olabilecektir. Bu sayede esas olarak, gelecek olan halkın Toplum 5.0 bağlamında sosyal koruma fikri ve pratikleri açısından ne tür bir toplumsal perspektif üretebileceği sorunsallaştırılmış olacaktır. Düşüncenin üretimi ile bunun bilgi koşullarıyla ilişkisi, yani çalışma özelinde bilimsel araştırmayı ve teknolojik gelişmeyi bir toplumsal ufuk haline getirme meselesi (toplumsal masal yaratmak kavramı kullanılacaktır), sosyal korumanın yeni bilimsel ve toplumsal koşullarla kavranabilmesinin ana unsurları olarak yer bulacaktır.

Bilimsel araştırmayı ve teknolojik gelişmeyi ön plana alan dijital temelli bir toplumsallığın oluşumunu irdelemek, yukarıda belirtilen kavramsal ve tematik hususların anlaşılabilmesiyle koşut halde yürütülecektir. Böylece dijital temelli bir toplumsallığa doğru yönelişin sosyal korumayla olan etkileşimini, dönüştürücü bir toplumsal tasarımın kendisiyle birlikte taşıyabileceği koruma fikri bakımından

\footnotetext{
_userdata/abenomics/pdf/society_5.0.pdf.

3 "Realizing Society 5.0 ".

${ }^{4}$ Gilles Deleuze, “Edebiyat ve Yaşam”, Kritik ve Klinik, çev., İnci Uysal, İstanbul: Norgunk Yayıncllık, 2013, s.13-14.
} 
kavrayabilmek mümkün olacaktır. Burada, düşüncenin üretimi ve bunun bilgi koşullarıyla ilişkisinin oluşturduğu ağların güncel bir örneği olan sorunsalın, işleyişlerinin ve imkânlarının gözetilme gereği bulunur. Zira ancak bu sayede; bilimsel, teknolojik ve toplumsal unsurlara temas edebilecek olan bu çerçeveden hareketle, hakikati araştırmak ve toplumsal masal yaratmak kavramlarının birbirine yakınsamasıyla ifade edilecek bir bakış açısını, toplumu koruma fikri bağlamında anlayabilmek amaçlanabilecektir.

\section{Gelecek Olan Halk ve Toplum 5.0}

Gelecek olan halk yaklaşımını, akıl (rasyonel akla atıfla) ve güdü (organizmayı yönlendiren sosyal güdülere atıfla) gibi karşıt olduğu kabul gören yönleri bulunan iki kavram üzerinden - bilimsel olan gözlemler ve deneyimsel olan görüşler gibi bir başka ikiliye de ilişkin - sunabilmek mümkündür. Bu sayede aklın ve güdünün bir araya gelip birlikte hareket etmek suretiyle oluşturmakta olduğu sorunsallar çalış1labilir. Bergson'un belirttiği üzere bu iki kavram ve pratikleri, birbirlerine olan ihtiyacı da gösteren bir şekilde yaşamda yer tutar. Esasen yaşam içinde saf bir akıl veya güdü bulunmaz, diğer bir deyişle etrafını aklın kuşatmadığı bir güdü olmadığı gibi, güdünün izlerini taşımayan akıl da yoktur. Bu bakımdan akla götüren çizgi, zeka belirtileri gösteren varlıklarda bir tür güdüye, yani akıl vasıtasıyla aklın çalışmasını güdümleyebilen kurgusal temsilleri de icat eden ve masal yaratma (fabulation) olarak ifade edilebilir bir özelliğe de yer vermektedir. ${ }^{5}$

Doğanın bir parçası olan toplum içinde insan belirli aralıklar içinde, bir olaydan diğerine veya bir kavramdan diğerine gönderiliyor gibidir. Fakat Bergson'a göre toplum ile akıl ilişkisi üzerinden kavranabilir olan bu aralıklara (farklılaşmalara) bir şey gelip koşulları değiştirdiği ölçüde durum dönüşebilir. İşte bu aralıklarda hareket eden yaratıcı heyecan (Bergson felsefesinde élan vital; Deleuze'ün materyalist felsefesindeki yorumuyla, günümüz bilimsel araştırmalarında sunulan haliyle yaşamın beliren özellikleri - emergent properties - olarak kavranacaktır), hem akla dayalı olabilen bireysel bencillikten hem de bir nevi güdüsel olabilen toplumsal baskı ve bağlı olarak masal yaratmaktan, doğa bakımından farklıdır. ${ }^{6}$

Yaşamı potansiyel olan güçleriyle birlikte düşündügümüzde, yaşamın beliren özelliklerinin ${ }^{\star}$ mevcut tüm tasarımların ötesinde yeni fikir ve olaylardaki etkinliği tespit edilebilir. Deleuze'e göre bu yaratıcı güç, Bergson düşüncesinde, insanı yaratım sürecine uyarlayabilmek için onu kendi planından özgürleştirmeyi ifade eder. Toplumun parçaları söz konusu yaratıcı heyecana açılmak suretiyle yaşam hareketini anlama çabası içinde onun yaratımına katılmaktadır. Bu ise belirli ölçüde akıl ile güdünün bir araya gelmesiyle farklı bir bilişselliğin, sezginin (intuition) oluşumudur. Fakat yine de Bergson için masal yaratmak, önerilen toplumsallığın sürekli tahkim edilmesine işaret edişiyle, olumsuz bir süreç olarak görülür: Kapalı toplumsallıkların oluşturucusu olan bir işlev gösterir. Buna karşın; sanat, felsefe ve bilimde, bir taraftan akıl vasıtasıyla aklın çalışmasını güdümleyebilen kapalı toplumsallıklar yaratılabilirken, diğer taraftan yaşamın beliren özellikleri sayesinde akıl ve güdü arasında ortaya çıkarak yaşam hareketine katılan bilim, felsefe ve sanat da söz konusu olabilir - her iki yön Toplum 5.0 kapsamında düşünülecektir. Düşüncenin bu üç temel formunda, her iki yönün de farklı oranlarda bulunabileceğini ifade

\footnotetext{
${ }^{5}$ Henri Bergson, Ahlakın ve Dinin İki Kaynă̆ı, çev., M. Mukadder Yakupoğlu, Ankara: Doğu Batı Yayınları, 2013, s.106-107.

${ }^{6}$ Bergson, Ahlakın ve Dinin, s.121-125.
} 
eden Deleuze, bu bağlamda masal yaratma işlevinde olumlayıcı bir potansiyel de görür. Geleceği veya henüz olmayanı ele aldığımızda, ütopya gibi bir kavram - ideallere gönderme yapan aşkıncı bir modelleme - yerine masal yaratma kavramını, yani aktüel olanı işlerken onunla birlikte hareket etmekte olan potansiyel olanı değerlendirmeye işaret eder. ${ }^{7}$

Bu kavram çalışma açısından, akla ilişkin olarak bilim ile güdüye ilişkin olarak deneyimin etkileşimi kapsamında yeni kavramların, fikirlerin, kurumların oluşumu üzerinden düşünülebilir haldedir. Esas olarak örneğin bir kavramın yaratılması bir gelecek formuna çağrı yapar; yeni toplumsal düzenlemelere ve henüz olmayan halklara (peuple qui manque) ya da gelecek olan halklara (peuple à venir) seslenir. Sanatta, felsefede, bilimde eksikliği görülen bir düzenlemenin veya bir halkın oluşa girmesi (devenir: becoming) için seslenilen, henüz minör olan halktır. Deleuze'ün belirttiği üzere sanatçı - bilim insanı ya da düşünür de diyebiliriz - bir halkı şüphesiz ki yaratamaz, fakat onu güçleriyle, çağırabilir; yani sanat, felsefe ve bilimin fikirleri ve ürünleri yeni bir toplumsallığın gelişini hazırlayabilir, içlerinde taşıyabilirler. O nedenle bir halkı icat etmek, tanımlandığı şekliyle masal yaratmanın bir işlevi olmaktadır. Bu ise yazarın, düşünürün, bilim insanının içinde yer bulabildiği, gelecek olan halka dairdir. ${ }^{8}$

Bu bağlamda gelecek olan halk kavramının çalışma bakımından, mevcut insan formu ve ürettiği sosyallikler ile yeni Toplum 5.0 düzenlemesinin getirmekte olduğu kuvvetlerin bileşkeleriyle, birlikte sorunsallaştırılabilmesi mümkündür. İnsanın temas edebileceği ve dönüşebileceği farklı kuvvet alanları bulunur ve bunlar da dönüşümleri kendi sorunsallarıyla (çalışma konusunda olduğu gibi) birlikte getirmektedir. Organik ile inorganik yaşamın, insan ile teknolojinin esas olarak aklın yaratmakta düşünce (örneğin bilim) ve güdüleri içerebilen deneyimin (örneğin muhtelif yönleriyle toplumsal yaşam) etkileşimlerinden doğuracağ güçler; pratik ve söylemleriyle sanat, felsefe ve bilimin yeni yaşam potansiyellerinde açllımlar sergilemektedir.

O nedenle gelecek olan halk perspektifinden bakıldığında; yeni bir toplumsallık, aktüel bir durumun içinden ortaya çıkışı bağlamında, düşünce ve bilginin mevcut koşullarını ve bunların değişimlerini ele almak anlamına gelmelidir. Burada gelecek olan halk; sanat, felsefe ve bilimle, henüz bilinmeyenden, kavranamamış olandan, araştırılmakta olan hakikatten (gerçekten) artık $d$ ışarı çıkıyormuş gibidir. ${ }^{9} \mathrm{O}$ anlamda hakikati araştırmanın gelecek olana açılma niteliği; yaşamın yeni kuvvetlerinin, öznellik tarzlarının ve araştırma biçimlerinin etkileşimini ifade eder. $\mathrm{Bu}$

\footnotetext{
${ }^{7}$ Gilles Deleuze, “Denetim ve Oluş”, Müzakereler, çev., İnci Uysal, Norgunk Yayıncılık, 2013, s.184.

*Biyolojik sistemlerden örnek vermek gerekirse; bir hücrenin çalışmasının kritik yönlerinin çoğu, birlikte hareket eden moleküler parçaların ortak davranışından kaynaklanır. Genellikle "beliren özellikler" olarak adlandırılan bu kolektif özellikler, biyolojik sistemlerin kritik nitelikleridir, zira tek tek parçaları anlamak sistem davranışını anlamak veya tahmin etmek için yetersizdir. Beliren özellikler sistemin parçalarının etkileşiminden ileri gelir. Örneğin insan beyninde depolanan bellek, tek nöronun ya da birçok nöronun bir özelliği olarak anlaşılamaz. Birlikte hareket eden nöronların belirmekte olan ortak özelliğidir. Yaşam; sistem ve parçalarının etkileşimi, ilişkileri ve ortak özellikleri üzerinden tanımlanır. (Encyclopaedia Britannica, "Systems Biology" maddesi, erişim 25 Mart, 2021, https://www.britannica.com/science/systems-biology.) Karmaşıklık ve beliren özellikler, evrim, ağlar ve enformasyon gibi hususlar içeren bir konudur. Makalenin felsefi temeli açısından yaşamın sürekli olarak kendini üretmekte olduğu farklılaşma (différentiation) hareketine karşlık gelir.

${ }^{8}$ Deleuze, "Edebiyat ve Yaşam", s.13-14.

${ }^{9}$ Gilles Deleuze ve Felix Guattari, Felsefe Nedir?, çev., Turan Ilgaz, İstanbul: Yapı Kredi Yayınları, 2000, s.194.
} 
sayede ortaya çıkabilecek fikir ve kurumlarsa; hem düşünce hem de deneyimin etkin olduğu, hem bilimin ve teknolojinin imkanlarının hem de günümüzün buna dair yeni sorunlarının (gerçek-sonrası/post-truth, dijital suçlar, blokzinciri ekonomisinin denetimi vb.), yani Toplum 5.0 düzlemine ilişkin olanların ve bunun düzenlemelerinin, imkanları ve sorunlarıyla - bir arada sorunsallarıyla denilebilir düşünce ve bilgi koşullarını sunmaktadır.

$\mathrm{Bu}$ bakımdan hakikatin araştırılması ile toplumsallığın biçimlenmesi, düşüncenin üretimi ve bilginin koşullarının ilişkisi bağlamında sürekli etkileşim içindedir. Hakikatin araştırılması, esasen toplumsal pratiklerin de dahliyle meydana gelen bazı biçimlerde görünür olmaktadır. Foucault'ya göre söz konusu biçimlerin (ortaçağda soruşturmanın [enquête: inquiry] ortaya çıkışı, modernitede incelemenin [examen: examination] yükselişi gibi) oluşumları ve etkileriyle muhtelif düşünce ve bilgi alanlarındaki işleyişleri önem arz eder. Buna göre toplumsal pratikler; kavram ve tekniklere etki etmenin haricinde, yeni öznellik biçimleri de doğuran bilgi (savoir) alanları sunar. Söz konusu pratikler toplumun; öznellik türleri, bilme usulleri ve sonuç olarak insan ile hakikat (vérité) arasındaki ilişkilerin ifade edildiği biçimleri meydana getirirler. ${ }^{10}$

Bu kapsam içinde hakikati araştırmanın hem bilimsel hem de toplumsal biçimlerinden hareketle ulaşılabilecek yeni toplumsal ufuklara, çalışmadaki ifadeyle toplumsal masal yaratma tarzlarına işaret edebilir. Örneğin Toplum 5.0 düzleminin ve bunun düzenlemelerinin oluşması, ilgili fikirlerin ve fenomenlerin yaygınlığıyla, gelecek olan bilimselliğe ve toplumsallığa vurgu yapmasıyla, bu bakış içinde irdelenebilir haldedir. O nedenle bu aşamada Toplum 5.0 düzlemini bazı temel hususlarıyla belirlemenin ardından, sorunsallaştırmanın içine dâhil etmek uygun olacaktir.

Toplum 5.0 kavramı, Japonya'nın 5. Bilim ve Teknoloji Temel Planı'nda 2015 yılı itibarıyla yer bulmuştur. İlgili Plan'da Toplum 5.0 kısaca, siber alan ile fiziksel alanın birbirine entegre olacağı, geleceğin toplumu olarak süper akıllı toplum ifadesiyle tanımlanır. Süper akıllı toplum, teknoloji vasitasıyla ürün ve hizmetlerin insanlara ihtiyaç olan miktarda sağlandığı, insanların muhtelif toplumsal farklılıklarına önem verilmek suretiyle yüksek kalitede ürün ve hizmet alabildiği, çözüm ve insan odaklı bir toplum şeklinde sunulmuştur. ${ }^{11}$

Toplum 5.0 kavramı, Almanya'nın Hannover şehrinde 2017 yılında teknoloji fuarı CeBIT'de Japonya Başbakanı Shinzo Abe'nin konuşmasında yaptığı atıfla günümüzdeki yaygınlığına kavuşur. Abe, insanlığın mevcut sorunlarına çözümler bulabilmek üzere insanlık tarihinin beşinci evresinin başlangıcında olduğumuza işaret etmiştir. Nesnelerin birbirine entegre olacağ 1 ve teknolojilerin birleşeceği Toplum 5.0 çağı, insanlığın faydası yönünde bir gelecek ufku olarak vurgulanır. ${ }^{12}$

\footnotetext{
${ }^{10}$ Michel Foucault, "Hakikat ve Hukuksal Biçimler”, Büyük Kapatılma, Seçme Yazılar 3, der., Işık Ergüden ve Tuncay Birkan, çev., Işık Ergüden, İstanbul: Ayrıntı Yayınları, 2011, s.164-168.

11 "Report on the 5th Science and Technology Basic Plan", Council for Science, Technology and Innovation, Cabinet Office, Government of Japan., erişim 12 Mart, 2021, https://www8.cao.go.jp/cstp/kihonkeikaku/ 5basicplan_en.pdf.

12 "CeBIT Welcome Night”, Speeches and Statements by the Prime Minister Shinzo Abe, erişim 12 Mart, 2021, https://japan.kantei.go.jp/97_abe/statement/201703/1221682_11573.html.
} 
Söz konusu açıklamaların temel bulduğu Japonya Bilim, Teknoloji ve İnovasyon Kurulu ise esas olarak çağımızın bilgi toplumunda enformasyonun muhtelif sistemler arasındaki entegrasyonunun yetersiz olduğunu belirlemektedir. O nedenle Toplum 5.0 ile birlikte nesneler siber alan sayesinde sistemlere bağlanacaktır. $\mathrm{Bu}$ kapsamda Toplum 5.0, siber alandaki büyük verinin yapay zekayla geliştirilerek elde edilenlerin kazanımların fiziksel alanda toplumun kullanımına açılacağı bir ufka vurgu yapar. Toplum 5.0'da nesneler, insanlar ve sistemlerin siber alanda birbirine bağlanmak suretiyle fiziksel alana kullanımlar sunabilmesi amaçlanacaktır. ${ }^{13}$ Toplum 5.0'in getirebileceği değişimlerin, teknoloji üzerinden sosyal sorunlara karşı insan merkezli çözümler üretmek yoluyla zemin oluşturacağı planlanmaktadır ki çalışmada ele alınmakta olan sosyal koruma fikrine de bu yönüyle temas etmektedir.

\section{Toplum 5.0 ve Sosyal Koruma}

Toplum 5.0 Japonya devleti tarafindan, Toplum 5.0'a Ulaşma Reformu kapsamında ana gereklilikleriyle sunulmuştur. Buna göre toplumsal yaşama Endüstri 4.0'ı entegre ederek sorunları çözebilme amacıyla beş temel konu; hareketlilik devriminin gerçekleştirilmesi, yeni nesil tedarik zinciri oluşturulması, sağlıklı yaşam süresinin uzatılması, finansal teknoloji ile uygun altyapının geliştirilmesi olarak tespit edilmiştir. ${ }^{14}$ Tüm bu hususların gerçekleştirilmesinin toplumsal bir dönüşümü gerektirmekte olduğu açıktır.

Dönüşümün sağlanabilmesi amacıyla üstesinden gelinmesi gereken engeller ise Japon Ekonomik Organizasyonlar Federasyonu tarafından tanımlamıştır. Bunlar; teknolojik engeller, sosyopolitik engeller, nitelikli insan kaynağı meselesi, hukuk sistemine ilişkin engeller ve toplumsal direnç olarak gösterilir. Teknolojik engeller bakımından yapay zeka, robotik, nanoteknoloji, biyoteknoloji gibi alanların teşviki ve inovasyonla ilgili çerçevenin geliştirilmesi öne sürülmektedir. Sosyopolitik engellerin aşılabilmesi için sanayi, akademi ve devlet katılımıyla stratejilerin hayata geçirilmesi ve ilgili platformlarla kuruluşların oluşturulması önerilmektedir. Nitelikli insan kaynağı açısından halkın katılımına yönelik eğitim reformu kapsamında yaratıcılık, bilgi teknolojileri okuryazarlığı, veri bilimi gibi alanların teşviki öne çıkmaktadır. Hukuk sistemi için ise veri kullanımı üzerine kurallar geliştirilmesi, teknolojik düzene uygun düzenlemelerin ve reformların gerçekleştirilmesi önerilmektedir. ${ }^{15}$

Engel olarak görülen alanlar ve çözüm önerileri, engellerden biri olarak belirtilen toplumsal direnç açısından her birine temas etmesi nedeniyle gözetilebilirler. Toplumsal direnç temelde, yeni sosyal akışkanlıklar ile bunların sunmakta olduğu ufuklar üzerinden (engelleri, çözümleri, karşı tezleriyle) okunabilir; ufkun ve direncin, araştırma-geliştirmenin ve deneyimlemenin çizgilerinin kesiştiği, çatıştı̆̆ 1 veya örtüştüğü akışkanlıkların bizzat içindeyken durumla ilgili değerlendirmeler ve geliştirmeler yapılabilir. Bu durum ise çalışmanın, hakikati araştırmak ve toplumsal masal yaratmak olarak tanımlanmakta olan hususlarının etkileşim halinde

\footnotetext{
13 "Report on the 5th Science and Technology Basic Plan".

14 "Realizing Society 5.0".

15 "Toward Realization of the New Economy and Society: Reform of the Economy and Society by the deepening of Society 5.0", Keidanren Japan Business Federation, erişim 12 Mart, 2021, https://www.keidanren.or.jp/en/ policy/2016/029_outline.pdf.
} 
olduğu bir çerçevesi içinde sorunsallaştırılabilir haldedir. Yeni ufukların ve toplumsal dirençlerin bu çerçeve içinde konumlar ve pratikler buluşunda olduğu gibi, özgül olarak toplumu koruma fikrinin ve pratiklerinin de Toplum 5.0'in önermekte olduğu toplumsallıkla biçimlenebilir oluşu ve bunun olası koşulları ise kavranmaya çalışılan meseledir. Söz konusu kavrayışı geliştirebilmek amacıyla bu aşamada sosyal koruma üzerine temel bazı hususları belirtmek uygun olacaktır.

Sosyal korumayı öncelikle bilimsel, teknolojik, üretimsel ve diğer gelişmelerin kaydedilmekte olduğu ve iktisadi bir büyüme (niteliksel bakımdansa kalkınma) sağlamaya çalışan bir toplumsal yaşam içinde konumlandırarak bir giriş yapılabilir. İktisadi büyüme esas olarak sermaye, emek, doğal kaynaklar, girişim gibi üretim faktörleri sayesinde mal ve hizmet üretiminde oluşan artıştır. Bu kapsam içinde bilimsel-teknolojik gelişme, fiziki sermaye ve beşeri sermaye birikimi iktisadi büyümeye kaynak oluşturmaktadır. Büyümenin sağlanabilmesi için kaynakların birlikte çalışmasına ihtiyaç duyulur. ${ }^{16}$ Bunların düzenli çalışabilmesi ve toplumsal yaşamla örtüşebilmesi için ise geniş çapta bir dizi sosyal politikaya gereksinim bulunmaktadır ki sosyal korumayı da söz konusu kapsam içinde konumlandırmak mümkündür.

Buna göre sosyal politikayı değerlendirmek, esasen sosyal politika kurumlarını ve aralarındaki işbölümünün niteliğini değerlendirmektir. Devlet, aile, piyasa, sivil toplum örgütleri olan bu kurumlar arasındaki ilişki, ilgili toplumun sosyal koruma rejimini ortaya çıkarmaktadır. O sayede sosyal politika; adalet, barış, hakça üretim ve bölüşüm, gelir dağılımı dengesi gibi sosyoekonomik meselelere önem vermek suretiyle sağlıklı bir kalkınmanın gerçekleştirilebildiği bir toplumsal ufka da işaret etmektedir. Zira sosyal politika tüm bireylerin toplumda bulunan sosyal ve ekonomik imkanlardan dengeli ve eşit paylar alabilmesi yolunda bir düzenlemeler bütünüdür. ${ }^{17}$

Sosyal korumanın mikro ve makro düzeyde büyüme ve kalkınmayı etkileyebildiği muhtelif kanalları bulunur. O nedenle sosyal koruma, sosyoekonomik hedeflere yardımcı olabilecek bir sosyal politika müdahalesi olarak da görülür. Üretkenliği ve işgücüne katılımı artırmak için iktisadi büyümeye olumlu etkilerinin bulunduğu bazı araştırmalar tarafından tespit edilmektedir. ${ }^{18}$ Sağlanan büyümeye rağmen ekonomik problemler içinde olanları kapsayacak sosyal koruma sistemleri önem kazanmaktadır. Bu görüşe göre iktisadi büyüme, kalkınmanın temelinde olup refahı arttırmak için esas unsur olarak görülür. Bu bağlamda sosyal koruma, uzun dönem içinde iktisadi büyüme üzerinde güçlü bir değişken olarak onu olumlu yönde etkilemekte ve kapsayıcı bir büyüme için etkin bir sosyal politika aracı olabilmektedir. Sosyal korumanın iktisadi büyümeye etkisini sağlamak üzere en doğru planlama ve uygulama özelliklerini belirlemenin sosyal politika kararlarının ana parçasını oluşturduğuna dair bir bakış açısı mevcuttur. ${ }^{19}$

\footnotetext{
${ }^{16}$ Selman Yılmaz, Makro Ekonomik Teoride Yatırım, Büyüme ve Enflasyon, İstanbul: Beşir Kitabevi, 2004.

${ }^{17}$ Doğa Başar Sariipek, “'Hak Temelli' Sosyal Politikadan 'Hayırseverlik Temelli’ Sosyal Politikaya Geçişte Sivil Toplum Örgütlerinin Rolü”, İnsan ve İnsan Dergisi, 11 (2017), s.81-82.

18 Albert Berry, "Growth, Employment, Poverty and Social Protection: A Conceptual Framework", Social Protection, Growth and Employment: Evidence from India, Kenya, Malawi, Mexico and Tajikistan, der., United Nations Development Programme, New York: UNDP, 2013, s.26-27.

${ }^{19}$ Hakan Kum ve Özlem Öktem, "Düşük Gelirli Ülkelerde Sosyal Koruma ve Ekonomik Büyüme İlişkisi”, Ekonomi, Politika \& Finans Araştırmaları Dergisi, 3/3 (2018), s.342.
} 
Bununla birlikte daha geniş çapta sosyal politika; ekonomik, kültürel, sosyal, siyasal gibi çeşitli değişkenlerle gelişmekte ve biçimlenmektedir. O nedenle de karşılık olarak; sağlık, eğitim, barınma, beslenme gibi ihtiyaçlar için sosyal refahın planlama ve uygulama boyutları üzerine etkin olabilmektedir. Kısacası, toplumda üretilen refahı tüm vatandaşlara yayabilmek amacıyla kullanılan politika ve sosyal hizmetler, sosyal politika çerçevesinde görülmektedir. ${ }^{20}$

Tüm sözü edilen yönler hem devlet hem de devlet dışı kurumlar tarafından oluşturulan düzenlemeler olarak sosyal yaşamı şekillendirir. Bu hususta toplumsal fayda, iktidar ve direnç kuvvetleri gibi birçok yaşamsal çizginin bazen çatışmakta bazen birbirine eklemlenmekte ve hatta iç içe geçmekte oluşu söz konusudur. Öyleyse bunların yaşamın çoğul akış dinamiğini ya da özgürleşme yollarını tıkayabilen boyutlarına eleştirel bakmak ve bunları değiştirebilme imkanları önem kazanmalıdır. Bu mesele aynı zamanda mevcut bilgi ve düşünce koşullarına da değinmekte, hakikati araştırmak ile yeni toplumsal ufuklar aramak - masal yaratmak kavramında olduğu gibi - arasındaki ilişkinin ne denli yaşamı biçimlendirmekte olduğunu kavramak ve bunu sorunsallaştırmak - örneğin bilimin, felsefenin, sanatın yapabileceği gibi - anlamına gelmektedir. Sosyal koruma fikrinin ve pratiklerin de Toplum 5.0 süreciyle birlikte konumlanabileceği yeni ufuklar ve bunun dirençleri gibi bir bağlamı, toplumsal masal yaratma ile hakikati araştırmanın etkileşiminin oluşturmakta olduğu bir çerçeve içinde görürken, mevcut düşünce ve bilginin koşullarının değişimine vurgu yapılmalıdır. Değişimin iktidar ve direnç kuvvetleri arasında biçimlenişinde ve kuvvetlerin de yer değiştirebilmesinde toplumu koruma fikrini ve pratiklerini izleyebilmek, yaşamın içindeki kuvvet ilişkilerinin (gücün) analizine ihtiyaç duyar. Bu bakımdan toplumu biyo-iktidara oranla güçlendirmek olarak da ifade edilebilecek olan bir bakış açısını, çalışmanın boyutu ölçüsünde değerlendirmek isabetli olacaktır.

Michel Foucault araştırmalarına dayanarak 19. yüzyılın başlarından itibaren Avrupa'da iki tür iktidar teknolojisinin - bunların sosyopolitik yayılmalarından "çevre" de payını çokça almıştır - yer bulduğunu belirlemiştir. Bunlar, bir taraftan beden üzerinde yoğunlaşan, bireyselleştirici olan, yararlı ve uysal kılınması gereken kuvvetlerin kaynağı olarak bedeni manipüle eden disipliner bir teknoloji ile diğer taraftan nüfusa özgü kitle etmenlerini bir araya getiren, buna bağlı olaylar dizisini denetlemeye çalışan bedene değil yaşama odaklanan bir teknolojidir. Disipliner olan daha ziyade 18. yüzyılın başında, bölgesel düzeyde okul, hastane, kışla, atölye gibi kurumların çerçevesinde dolaşıma girmiştir. 18. yüzyılın sonlarında ise insan kitlelerinin biyolojik ve biyo-sosyolojik süreçleriyle nüfus fenomenleri üzerine daha karmaşık organizasyonları gerektiren ikincil bir girişim ortaya çıkmıştır. ${ }^{21}$

Öyleyse ilki beden-organizma-disiplin-kurumlar ve diğeri nüfus-biyolojik süreçler-düzenleştirici mekanizmalar olmak üzere iki dizi söz konusudur: Kurumların organik disiplini bir yanda ve devletsel bir bütün olarak biyo-düzenlemeler diğer yanda işler hale gelmiştir. Bu kapsamda Foucault'nun belirttiği üzere örneğin 19. yüzyılda yükselen düzenlemeler olarak tıbbi kurumlar, yardım sandıkları, sigortalar gibi bir dizi devlet-altı kurumlar, aynı zamanda devlet düzeyinin altında da yer

${ }^{20}$ Sariipek, "Hak Temelli”, s.83-84.

${ }^{21}$ Michel Foucault, Toplumu Savunmak Gerekir, çev., Şehsuvar Aktaş, İstanbul: Yapı Kredi Yayınları, 2002, s.254-255. 
bulurlar: Hastalık ve yaşlılık sigortası sistemleri, yaşam süresinin arttırılmasını sağlayan sağlık kuralları, sivil örgütlenmelerin cinsellik üzerinde yönlendirmeleri, çocuklara gösterilen bakımlar, öğrenim oranı vb. Esasen çoğu zaman bedene yönelen disiplinci mekanizmalar ile nüfusa yönelen düzenleștirici mekanizmalar birbirine eklemlenmektedir. ${ }^{22}$

Kısacas1 19. yüzyılda iktidar, disiplin teknolojileri ile düzenleme teknolojilerinin çifte işleyişi vasıtasıyla organik olandan biyolojik olana, bedenden nüfusa doğru tüm yüzeyi kaplamaya başlar. Bu, beden ve nüfus kutuplarıyla birlikte yaşamın sorumluluğunu üstlenen biyo-iktidardır. ${ }^{23}$ 20. yüzyıla da uzanmış ve onu güdümlemiş olan iki tür iktidar teknolojisinin etkilerini, sosyal politika kurumlarının biçimlenmesinde bazıları yukarıda sayılmış olan düzenlemelerle görmek mümkün olduğu gibi, toplumların özgün sosyal koruma rejimlerinin ortaya çıkışında da yönetimsellik (governmentality) boyutuyla tespit edilebilirler. ${ }^{24} \mathrm{Bu}$ ise esas olarak çalışmanın işaret etmekte olduğu mevcut düşünce ve bilgi koşullarını değiştirebilen hakikat araştırması ile yeni toplumsal masallar yaratılması arasındaki ilişkinin bizzat içinde konumlanır. Bedenler ve nüfusların ya da kurumlar ve mekanizmaların disipliner ve aynı zamanda denetleyici işleyişlerinin oluşturulmasıyla hem sosyal korumanın hem de toplumsalı yönlendirmenin muhtelif düzenlemeleri şekillenmektedir. Bu aşamada meseleye dair tarihsel bir perspektife kısaca değinmek konu açısından daha fazla aydınlatıcı olacaktır.

\section{Hakikati Araştırmak, Masal Yaratmak, Toplumu Korumak}

Tarihsel olarak sırasıyla hükümranlık dönemlerinin feodal üretimi, disiplin toplumlarının Marx’ın emeğin biçimsel boyunduruğu olarak isimlendirdiği çağ ve düzenleştirici toplumlarınsa emeğin gerçek boyunduruğu olması şeklinde bir dönemleştirme; sermaye ve toplum ilişkileri üzerine olan süreçlerin temel çizgilerini ortaya çıkarır. Bir başka deyişle; bireysel emekten, önce toplumsal emeğe ve bunun ardından toplumsal sermayeye geçiş yer bulur. Hardt'a göre bu geçişte gittikçe baskınlaşan karakter, sivil toplumun disiplinleştiren kurumlarının geri planda kalışlarıyla, sosyoekonomik koşullarının zayıflamasıdır. Zira artık hız, akışkanlık ve esneklik yeni dönemsel paradigmayı tanımlamaktadır. Piyasaların bir toplumsal denetim aracı haline gelişiyle, hem küresel sistem hem de yaşam tarzları bakımından bu yeni durum 20. yüzyılın ilerleyen dönemlerinin de ana dinamiği olmuştur. ${ }^{25}$ Önce Fordist üretim biçimini geri plana taşıyarak sosyoekonomik unsurlarını dönüşüme uğratan ve esnek üretim şekillerini sağlamış olan üçüncü sanayi devriminin getirdiği teknolojik gelişmeleri öne süren üretim paradigması ve ötesinde bu çalışmaya da temas etmekte olan zamanımızın dördüncü sanayi devrimi ve bunun zeki üretim sistemlerini ve teknolojilerini ortaya çıkaran üretim paradigması şekillenmiştir.

Bu çerçeve aynı zamanda, tüm bu dönüşümlerin üzerinde biçimlenmekte olduğu dönemlerin bilgi koşullarıyla olan ilişkisine temas eder. 1970'li yıllardan itibaren bilginin değişiminin değerlendirildiği postmodern durumda, bilgi toplumu kavramı ifade edilmiştir. Kapalı mekânlarda sunulan eğitimin disiplin toplumlarının

${ }^{22}$ Foucault, Toplumu Savunmak, s.256-257.

${ }^{23}$ Foucault, Toplumu Savunmak, s.259.

${ }^{24}$ Ceyhun Gürkan, "Foucault, Public Finance, and Neoliberal Governmentality: A Critical Sociological Analysis", Yönetim ve Ekonomi, 25/3 (2018), s.681.

${ }^{25}$ Michael Hardt, “Sivil Toplumun Çözülüşü”, Gilles Deleuze'de Toplum ve Denetim, der., ve çev., Barış Başaran, İstanbul: Bağlam Yayınları, 2005, s.102-106. 
bir özelliği olduğu, artık 20. yüzyılın sona yaklaştığı dönemde bilgiye ulaşmanın açık kanallardan olması fikri gündeme gelmiştir. Lyotard'ın belirttiği üzere verinin ilke olarak açık olması anlamında, tam bir enformasyon oyununda yöneltildiği biçimiyle, postmodern bilginin dünyası söz konusu olmuştur. ${ }^{26} 21$. yüzyılla birlikte ise zeki makinalar çağı kitleler için yeni bir toplumsallık oluşturmaktadır; bilgiyi işleyen zeki sistemlerin harekete geçmesiyle yeni bir dönem belirir. Buna göre toplumsal ağların ve bilgisayar ağlarının taşımakta olduğu enformasyonun işlenişi bu ikisinin eklemlenmesiyle tanımlanan Toplum 5.0'da olduğu gibi - geçmiş bilgi tarzından farklılaşırken, aynı zamanda politika, hukuk, demokrasi gibi kavramların da toplumsal alanda farklı bir konum kazanmaya başlamasının kanalları oluşmaktadır. O bakımdan genç kuşaklarla birlikte halk kavramı da değişim içinde gelecek olan halk kavramını değişimle birlikte okumaya imkân verir bir biçimde bulunmaktadır. Bilginin değişen kullanımları, üretim biçimleriyle etkileşimi ve metalaşmanın yeni değer ölçüleriyle birlikte yaşamın akış dinamiğinin bu güncel pratikleriyle toplumsal alan da farklılaşmakta, yeni imkânlar ve sorunlar gündeme gelmektedir.

Çalışma açısından Toplum 5.0 düzlemiyle gözetilmekte olan bu yeni toplumsallık, muhtelif düzenlemeleri biçimlendirebilecek bir güç olarak belirmektedir. Bu halde hem ekonomi-politiğe hem de üretilen bilginin ekonomisine ilişkin olarak bilimsel ve toplumsal üretimler, belirli koşullar altında yaşamın akış dinamiğinin düzenlenişleridir. Esasen yaşamın akış dinamiği ile bilimsel ve toplumsal üretim arasındaki ilişki tarihsel olarak değişmektedir. Üretkenliğin değişimiyle birlikte toplumsallığın yeni düzlemleri ortaya çıkar.

Bu kapsam içinde örnek vermek gerekirse biyopolitika okumasında Lemke'nin Avrupa Komisyonun'nun planına atıfla sözünü ettiği bilgi tabanl biyoekonomi (knowledge based bio-economy), biyobilimsel ürün ve hizmetlerin arttırılmasını vurgular. İlgili vizyonun temelinde bilimsel ve toplumsal üretimlerin entegrasyonu yoluyla piyasaların yeniden düzenlenmesi ve yaratılması bulunur. Benzer şekilde Ekonomik İşbirliği ve Kalkınma Örgütü'nün (OECD) The Bio-ecomony to 2030: Designing a Policy Agenda raporu da biyoekonomiye dönüşümü ortaya koymuştur. Burada biyoekonomi; ürünler, hizmetler ve süreçlerin potansiyel değerinin büyüme ve kalkınma yaratmak için kullanıldığı yeni bir toplumsallığın ekonomik işlemlerinin tamamı olarak tanımlanır. ${ }^{27}$

Bu türden yeni bir toplumsallığın temellenmekte olduğu bir bağlam olarak yoğun veri akışına dayalı inovasyonun, ülkelerin karşılaştığı ekonomik ve sosyal zorluklarla birlikte geldiği ifade edilmektedir. Örneğin Japonya'nın veriye dayalı inovasyonun faydasını arttırmak için sosyo-ekonomik riskler olan emek, sermaye ve bölgesel kalkınma üzerine riskleri azaltması gereğine işaret edilir. O nedenle geleceğe yönelik olarak bilim, teknoloji ve inovasyon faaliyetlerinin bir ekosistem halinde görülme perspektifi önem kazanmaktadır ki bu husus üzerine tarihsel bir dönüşümü de kavramak mümkün olabilecektir. Toplum için değer yaratarak sistem esnekliğini sağlayabilmek, söz konusu üç temel riski azaltmak ve Toplum 5.0'da üretkenliği ve kalkınmayı canlandırmak için gerekli görülür. ${ }^{28}$

\footnotetext{
${ }^{26}$ Jean-François Lyotard, Postmodern Durum: Bilgi Üzerine Bir Rapor, çev., Ahmet Çiğdem, Ankara: Vadi Yayınları, 1997, s.113.

${ }^{27}$ Thomas Lemke, Biyopolitika, çev., Utku Özmakas, İstanbul: İletişim Yayınları, 2013, s.146-147.

${ }^{28}$ Kayano Fukuda, "Science, Technology and Innovation Ecosystem Transformation Toward Society 5.0", International Journal of Production Economics, 220 (2020).
} 
Bu bakımdan Toplum 5.0 içinde sürdürülebilir inovasyon ön plana gelmektedir. Sürdürülebilir inovasyon; çevresel, finansal ve sosyal boyutlar üzerine olan sürdürülebilirliğin, fikir üretiminden Ar-Ge'ye ve sonuçların arzına kadar kuruluşların sistemlerine entegre edildiği bir süreç olarak anlaşllabilir. Bu durum ürünler, hizmetler ve teknolojilerin yanı sıra yeni iş ve organizasyon modelleri için de geçerlidir. Burada sosyal boyut; fırsat eşitliği, servet dağılımında adalet, kapsayıcı büyüme ve sosyal maliyetler gibi konular üzerine odaklanmaktadır. ${ }^{29}$

Japonya örneğiyle, aşılması gerekecek bu tür toplumsal zorluklar vurgulanabilir. Azalan bir doğum oranı artan yaşlı nüfusla birleştiğinde, azalan iş gücü ve artan sosyal güvenlik maliyetleri söz konusu olmaktadır. Japonya'da 77 milyon kişiyi aşan iş gücünün 2050 yılına dek 53 milyon kişi olma suretiyle \%70 oranında küçülmesi beklenmektedir. Ayrıca yaşlanma nedeniyle sosyal güvenlik maliyeti de artacaktır. Örneğin 2015 yılında 120 trilyon Yen olan maliyetin, 2025 yılında 150 trilyon Yen'e yükselmesi öngörülmektedir. Japonya'daki sosyal sermayeye bakıld1ğında, temel altyapının çoğunluğunun 1950'lerden 1970'lere kadar yüksek ekonomik büyümeyle oluştuğu tespit edilmektedir. Buna göre ortalama 50 sene içinde yollar, köprüler ve su tesisatları gibi altyapılar bozulmaktadır ve bunun için toplam 190 trilyon Yen bir bütçenin 2011 yılından 2060 yılına dek ihtiyaç olacağı hesaplanmıştır. Esasen Japonya'nın karşı karşıya olduğu bu toplumsal zorluklar, diğer birçok ülke için de geçerlidir. Hem ekonomik kalkınmayı hem de sorunlara çözüm getirmeyi talep eden bir dünya için kapsamlı bir sisteme ulaşmak önem arz eder. O nedenle zorluklara toplumsal bir kapsayıcılıkla yanıt vererek refahı gerçekleştirme yolunda toplumsal bir dönüşümün gereğine işaret edilmektedir. ${ }^{30}$

Esasen Toplum 5.0, Japonya'nın toplumsal zorluklara verdiği bir yanıttır. Bu türden yanıtların gerekliliğini öne süren Accenture Research tarafından Asya-Pasifik bölgesinde yürütülen bir iş araştırmasına göre robotik, blokzinciri, büyük veri, otonom sürüş, 3D baskı gibi dijital teknolojilerin doğru kombinasyonunun kurumsal maliyetleri çalışan başına \%27’ye dek azaltabileceği ve ilgili sektörlerde piyasa değerini ortalama \%28 oranında arttırabileceği sunulmuştur. Araştırma raporu, dijitalleşmeye uygun bir iş gücünün önemini belirtmek suretiyle, dijitalleşme ile kurumsal üretkenlik arasındaki ilişkiyi vurgulamaktadır. ${ }^{31}$

Dolayısıyla bilimsel ve toplumlar üretimdeki ve bunlara bağlı teknolojilerdeki dönemsel farklılıkların ekonomi-politikte ve üretilen bilginin ekonomisinde yer bulmasının yanı sıra, Lazzarato'nun kapitalizmde ekonomik ve teknolojik akışların aynı zamanda yeni bir toplumsallığın üretimiyle olan ilişkisi fikrine işaret edilmelidir. Bu bakımdan neoliberal kapitalizm tarafından muhtelif sosyalliklerin ve onlara dair teorilerin kapılıp kullanılmasında olduğu gibi, bilgi toplumu teorileri de yaratım ve yenilik süreçlerini anlamakta başarısız olup hem bilgi hem de kültür üretimi oluşturan ekonomilerin çoğulluğunu kapsamakta yetersiz kalabilmişlerdir. Genel anlamda üretimi yalnızca bilgi, dil ve kültürün üretimi olarak kavramak ise aynı çember içinde kapalı kalmak olmuş, olumsal bir toplumsallı̆̆ı üretmemiştir. ${ }^{32}$

\footnotetext{
${ }^{29}$ Sandro Serpa ve Carlos Miguel Ferreira, "Society 5.0 and Sustainability Digital Innovations: A Social Process", Journal of Organizational Culture, Communications and Conflict, 23/1 (2019), s.7.

${ }^{30}$ Mayumi Fukuyama, “Society 5.0: Aiming for a New Human-Centered Society”, Japan Spotlight, 37/4 (2018), s.47.

${ }^{31}$ Dave Abood vd., "Combine and Conquer: Unlocking the Power of Digital", Accenture Research, (2018), s.3.

${ }^{32}$ Maurizio Lazzarato, Signs and Machines: Capitalism and The Production of Subjectivity, çev., Joshua David Jordan, Los Angeles: Semiotext(e), 2014, s.18-19.
} 
İşte bu noktada gelecek olan halk yaklaşımıyla Toplum 5.0'ın sorunsallarından biri olan toplumu koruma fikrine işaret ederken, eleştirel bir bakış açısıyla da olumsal pratiklerin oluşma koşullarına değinmek mümkün olabilir.

Foucault'dan esinlenen biyopolitika ve yönetimsellik fikirlerinin sosyal politika çalışmalarına artan dahline rağmen uygulamalı araştırmacılar için bazı zorluklarının da söz konusu edilmesi üzerinden bu hususa bir giriş yapılabilir. Temel olarak Foucault sonrası yönetimsellik çalışmalarına yöneltilen devletin rolünü küçümsediği, direnişi yetersiz bir şekilde teorize ettiği gibi yargılarla birlikte, bu yaklaşımın eleştirel bir potansiyele sahip olduğu ve kullanımının araştırmacılara sosyal politika alanında yeni mücadele fikirleri için olanaklar sunduğu ifade edilmektedir: McKee'nin belirttiği üzere devletin amaçlarının istenen sonuçları gerçekleştirmede her zaman başarılı olacağını varsayma tuzağından kaçınma, zamana ve mekana daha duyarlı bir etnografik analiz kanalı, dünyanın karmaşık gerçeklerine karşı çok sesli uygulamalar, ilgili toplulukların deneyimleri ve bakış açıları, değişen iktidar tarzları arasındaki gerilimleri ve çatışmaları irdelemek gibi imkanlar vurgulanabilir. Bunu yaparken çağdaş toplumlardaki iktidarın çok yönlü ve değişken doğasını aydınlatabilecek yeni araştırma gündemleri söz konusu olabilmektedir. ${ }^{33}$

Bu bakımdan örneğin sosyal hizmet çalışmalarının gelecek için ne tür kanallar açabileceği önem kazanır. Garrett'a göre bunların toplumsal hareketlerle köprüler kurarak sağlayabileceği kazanımlar, sosyal adalet açısından da bir potansiyel olarak yönlendirilebilir. Böylece sosyal hizmet için eleştirel uygulama biçimleri geliştirilmek suretiyle uygulayıcıların hizmet alanlarla etkileşim kurma şekilleri değiştirilebilir. O sayede sorunları ve uygulamaları farklı açılardan görebilmek için yeni bir tür düşünce ve bilgi zemini sağlanabilir: Stratejik olarak sınıf, cinsiyet ve diğer kesişen sosyalliklerle ilgili daha geniş çaplı sorularla bağlantılar kurulabilir ${ }^{34}$ ki bunlar biyopolitik bir çerçeve içinde yeni bir toplumsal düzlem olarak Toplum 5.0 ve düzenlemelerinden biri olarak da toplumu koruma fikri ve pratikleri açısından geliştirilebilir.

Geniş çapta, hakikati araştırma biçimleriyle birlikte kavranabilir olan, Toplum 5.0 düzleminin ve bunun düzenlemelerinin doğuşuyla hareket kazanan, fikirler ve kurumlar gelişmektedir. Toplum 5.0 düzlemine doğru, bu durumun sosyal koruma gibi düzenlemelerinin oluşturmakta olduğu düşünce ve bilgi koşulları ile araştırma biçimleri söz konusu olacaktır. Toplum 5.0 da diğer düzlemler gibi bir düşünce ve bilgi ağları bütünü olarak şekillenirken, bir tarafta hakikatin muhtelif alanlardaki araştırmaları, biçimleri, birbirine geçişkenlikleri ile diğer tarafta bunların masal yaratma biçimleri üzerinden yeni toplumsallaşma kanalları söz konusudur.

Bu bağlam içinde fark yaratabilen, yeni düzenlemeleri oluşturan, güncelleşen fikirlerin ve kurumların günümüzün kapitalist akış dinamiğiyle olan ilişkilerinde, mücadelelerinde, analizlerinde gelişmekte olan yeni sosyallikler söz konusu olabilecektir. O halde gelecek olan halkların ve bunların toplumsal ufuklarının sosyal koruma fikriyle örtüşebileceği ya da çatışabileceği sorunsallar doğacaktır. Bu hususta Hardt ve Negri'nin belirttiği ortak iyilerin (common good) nasıl oluşturulabileceği

\footnotetext{
${ }^{33}$ Kim McKee, "Post-Foucauldian Governmentality: What does It Offer Critical Social Policy Analysis?", Critical Social Policy, 29/3 (2009), s.480.

${ }^{34}$ Paul Michael Garrett, Dissenting Social Work: Critical Theory, Resistance and Pandemic, Oxfordshire: Routledge, 2021, s.226-227.
} 
gibi bir temel mesele gündemde olabilmelidir. Doğal kaynakların kullanımı, eğitim, iktisat gibi toplumsal üretimlerin (günümüzde artık bilimsel üretimle ve bundan hareketle teknolojiyle eklemlenmiş hale geldiklerini de düşünerek) ortak varoluşun kurumlarına nasıl dönüştürülebileceği önem kazanır. Mesele, kurumların ve ortak iyilerin toplumsal katılım yoluyla ortaklaşa yönetilebilmesidir. Ortak iyilerin örgütlenmesi ve yönetilmesi, örneğin Rousseau'nun genel iradeyi her şeyin üzerinde bir bütün ve "herkesin iradesi”ni aşan bir şey olarak görmesinde olduğu gibi aşkıncı bir modele değil, toplumsala içkin olmaya işaret etmektedir. Zira ortak iyi herkes tarafından kurulması, yönetilmesi ve dağıtılması gereken bir süreçtir. Ortak oluş (becoming common), sosyalliklerin sürekli bir etkinliği olarak emperyal bir genel irade ufkuyla değil, herkesin iradesini birlikte dokuyan bir süreç halinde toplumsallığın yaratımıdır. ${ }^{35}$

Bu bakış açısına uygun olarak değerlendirilebilir olan gelecek olan halk kavramı, düşüncenin ve bilginin değişen koşullarında bir toplumsal masal yaratmaya söz konusu içkin süreci dikkate alarak gönderme yapmaktadır. Aktüel olanla birlikte hareket etmekte olan potansiyel imkânlar (ortak iyilerin kolektif olarak üretilmesi bakımından her an dönüşebilme ve güncelleşebilme gücü), toplumsal etkileşimlerin yönü üzerinde etkin olarak kullanılabilir ${ }^{36}$ ki bunlardan biri olan sosyal koruma bu türden bir bakışla ve ortak iyilerin yorumlanması ve değerlendirilmesi açısından geliştirilebilir.

Düşüncenin formlarından biri olan bilimden hareketle esas olarak teknoloji, bir taraftan akıl vasıtasıyla aklın çalışmasını güdümleyebilen kapalı sosyallikler oluşturabilecekken, diğer taraftan yaşamın beliren özellikleri halinde aklın ve güdünün birliğiyle yaşam hareketine katılan bilim ve teknoloji ise ortak iyilerin oluşturulup kullanımıyla söz konusu olabilecektir. Her iki yönü de Toplum 5.0 sürecinde deneyimlemek olası görünmektedir. Bu çerçeve içerisinde sosyal korumayı bir tür aktif mücadele ve müdahale pratikleri halinde kullanmak gerekecektir. Bu hususta biyo-iktidarın mikro ve makro düzeyde kuvvetlerinin de etkin olacağı aşikar bir süreç içinde geliştirilebilecek olan ortak iyi pratikleri düşünme ve eyleme gereği tespit edilebilir.

\section{Sonuç}

Güncel olarak araştırma biçimlerinin, bilimsel ya da toplumsal olarak oluşumları ile masal yaratma üzerinden yayılma kanalları, günümüz hakikatinin de aktüel sorunsallar olarak doğuşunu ifade etmektedir. Güncel iktidar ilişkileri ve bilgi koşullarını yenilemek için bu kez de Toplum 5.0 düzleminde masal yaratma denemeleri, yeni düşünme türlerinin ve hakikati araştırma biçimlerinin birbirleriyle etkileşimlerini gösterebilecektir. Böylelikle bu düzlemin, hakikati araştırmanın yeni biçimleri ile birlikte bunların bilimsel ve toplumsal işleyişlerini öne sürebilmesi mümkündür. Zeki sistemlerin bilim ve üretim süreçlerini yürütebildiği, farklı bilişsel düzeyleriyle sosyallikleri harekete geçirebildiği, kendi hareket planlarını veya yazılımlarının taslaklarını özgün sorunsallar halinde ortaya çıkarabildiği bir yeni toplumsal düzlemin koşulları söz konusu olabilecektir.

\footnotetext{
${ }^{35}$ Michael Hardt ve Antonio Negri, Duyuru, çev., Abdullah Yılmaz, İstanbul: Ayrıntı Yayınları, 2012, s.76.

${ }^{36}$ Ronald Bogue, "Fabulation, Narration and the People to Come", Deleuze and Philosophy, der., Constantin V. Boundas, Edinburgh: Edinburgh University Press, 2006, s.221.
} 
Düşüncenin ve bilginin bu gibi değişen koşullarının yer buluşuyla, dönüştürücü bir toplumsal tasarımın içinde taşıyabileceği koruma fikrinin değerlendirildiği bu çalışmada; dönüşüm ile korumanın, iktidar kuvvetlerinin sunabileceği yeni ufuklar ile buna karşın direnç kuvvetlerinin, ayrıca bir diğer düzeyde araştırma-geliştirme ile deneyimlemenin çizgilerinin esas olarak hem örtüşebileceği hem de çatışabileceği vurgusu yapılmaktadır. Toplumsal bir dönüşümün içinde taşıyabileceği koruma fikri ve pratikleri ile diğer taraftan koruma fikri ve pratiklerinin toplumsal bir dönüşümü yönlendirebilme gücü; araştırmanın, analizin, deneyimin biçimlendiği muhtelif fenomenlerde görünür olmakta, diğer bir deyişle sürekli olarak aktüelleşen fikirleri ve kurumları sergilerken, bazılarını potansiyelleştirmekte, sonraki evrelerin koşullarını oluşturmaktadır. Bunun pratik olarak anlamı, koşulların içinde saklamakta olduğu imkânların bizzat değişimi mümkün kıldığı, esas olanın kuvvet ilişkilerinin analizi ve bunları yönlendirme gücünün kullanımı olduğudur.

O nedenle bir pratikler dizisi olarak sosyal koruma da sözü edilen dijital temelli bir toplumsallığın oluşumunda yeni araştırma ve uygulama sahaları bulabilecektir. Dolayısıyla yeni oluşumlar ile mevcut koşulların birbirinden ayrılamaması, etkileşim halinde yeniyi ortaya çıkarması gibi, dönüşüm ve koruma da karşıtlık ilişkisiyle değil, çoğul bir akış dinamiğinin kısımları halinde okunduğunda, toplumu koruma pratiklerinin de bir tür toplumu dönüştürme pratikleri olarak yer bulmakta olduğu görülebilir. Bunların yönü ise yine ancak yaşamın akış dinamiğini çoğullaştıracak biçimde gerçekleştirildiğinde, olumsal pratikler olarak ortak iyilerin üretimine uygun olacak, aksi durumlarda yeni araçsallaştırma mekanizmalarının, sosyal borcun ve krizin parçalarına eklemleneceklerdir.

\section{Kaynakça}

Abood, Dave, Aidan Quilligan, Raghav Narsalay ve Vincent Cabanel. "Combine and Conquer: Unlocking the Power of Digital". Accenture Research. (2018): 120.

Bergson, Henri. Ahlakın ve Dinin İki Kaynă̆ı. Çev., M. Mukadder Yakupoğlu. Ankara: Doğu Batı Yayınları, 2013.

Berry, Albert. "Growth, Employment, Poverty and Social Protection: A Conceptual Framework". Social Protection, Growth and Employment: Evidence from India, Kenya, Malawi, Mexico and Tajikistan. Der., United Nations Development Programme. New York: UNDP, 2013: 1-39.

Bogue, Ronald. "Fabulation, Narration and the People to Come". Deleuze and Philosophy. Der., Constantin V. Boundas. Edinburgh: Edinburgh University Press, 2006: 202-223.

Council for Science, Technology and Innovation, Cabinet Office, Government of Japan. "Report on the 5th Science and Technology Basic Plan”. Erişim 12 Mart, 2021. https://www8.cao.go.jp/cstp/kihonkeikaku/5basicplan_en.pdf.

Deleuze, Gilles ve Felix Guattari. Felsefe Nedir?. Çev., Turan Ilgaz. İstanbul: Yapı Kredi Yayınları, 2000.

Deleuze, Gilles. "Edebiyat ve Yaşam”, Kritik ve Klinik. Çev., İnci Uysal. İstanbul: Norgunk Yayıncilık, 2013.

Deleuze, Gilles. "Denetim ve Oluş”, Müzakereler. Çev., İnci Uysal. İstanbul: Norgunk Yayıncilık, 2013.

Encyclopaedia Britannica. "Systems Biology" maddesi. Erişim 25 Mart, 2021, https://www.britannica.com/science/systems-biology. 
Foucault, Michel. Toplumu Savunmak Gerekir. Çev., Şehsuvar Aktaş. İstanbul: Yapı Kredi Yayınları, 2002.

Foucault, Michel. "Hakikat ve Hukuksal Biçimler", Büyük Kapatılma, Seçme Yazılar 3. Der., Işık Ergüden ve Tuncay Birkan. Çev., Işık Ergüden. İstanbul: Ayrıntı Yayınları, 2011.

Foucault, Michel. “Dışarı Düşüncesi”, Sonsuza Giden Dil, Seçme Yazılar 6. Der., Işık Ergüden ve Tuncay Birkan. Çev., Işık Ergüden. İstanbul: Ayrıntı Yayınları, 2014.

Fukuda, Kayano. "Science, Technology and Innovation Ecosystem Transformation Toward Society 5.0". International Journal of Production Economics. 220 (2020).

Fukuyama, Mayumi. "Society 5.0: Aiming for a New Human-Centered Society". Japan Spotlight. 37/4 (2018): 47-50.

Garrett, Paul Michael. Dissenting Social Work: Critical Theory, Resistance and Pandemic. Oxfordshire: Routledge, 2021.

Gürkan, Ceyhun. "Foucault, Public Finance, and Neoliberal Governmentality: A Critical Sociological Analysis”. Yönetim ve Ekonomi. 25/3 (2018): 677-694.

Hardt, Michael. “Sivil Toplumun Çözülüşü”. Gilles Deleuze’de Toplum ve Denetim. Der. ve çev., Barış Başaran. İstanbul: Bağlam Yayınları, 2005.

Hardt, Michael ve Antonio Negri. Duyuru. Çev., Abdullah Yılmaz, İstanbul: Ayrıntı Yayınları, 2012.

Keidanren Japan Business Federation. "Toward Realization of the New Economy and Society: Reform of the Economy and Society by the Deepening of Society 5.0”. Erişim 12 Mart, 2021, https://www.keidanren.or.jp/en/policy/2016/ 029_outline.pdf.

Kum, Hakan ve Özlem Öktem. "Düşük Gelirli Ülkelerde Sosyal Koruma ve Ekonomik Büyüme İlişkisi”. Ekonomi, Politika \& Finans Araştırmaları Dergisi. 3/3 (2018): 335-344.

Lazzarato, Maurizio. Signs and Machines: Capitalism and The Production of Subjectivity. Çev., Joshua David Jordan. Los Angeles: Semiotext(e), 2014.

Lemke, Thomas. Biyopolitika. Çev., Utku Özmakas. İstanbul: İletişim Yayınları, 2013.

Lyotard, Jean-François. Postmodern Durum: Bilgi Üzerine Bir Rapor. Çev., Ahmet Çiğdem. Ankara: Vadi Yayınları, 1997.

McKee, Kim. "Post-Foucauldian Governmentality: What does It Offer Critical Social Policy Analysis?”. Critical Social Policy. 29/3 (2009): 465-486.

Sariipek, Doğa Başar. " "Hak Temelli” Sosyal Politikadan "Hayırseverlik Temelli” Sosyal Politikaya Geçişte Sivil Toplum Örgütlerinin Rolü “. İnsan ve İnsan Dergisi. 11 (2017): 81-99.

Serpa, Sandro ve Carlos Miguel Ferreira. "Society 5.0 and Sustainability Digital Innovations: A Social Process". Journal of Organizational Culture, Communications and Conflict. 23/1 (2019): 1-14.

Speeches and Statements by the Prime Minister Shinzo Abe. "CeBIT Welcome Night”. Erişim 12 Mart, 2021. https://japan.kantei.go.jp/97_abe/statement/ 201703/1221682_11573.html.

The Government of Japan. “Realizing Society 5.0”. Erişim 12 Mart, 2021. https://www.japan.go.jp/abenomics/_userdata/abenomics/pdf/society_5.0.pdf.

Yılmaz, Selman. Makro Ekonomik Teoride Yatırım, Büyüme ve Enflasyon. İstanbul: Beşir Kitabevi, 2004. 